\title{
The Comparison of Constitutional Protection of Human Rights
}

\section{between China and South Africa}

\author{
Jian $\mathrm{He}$ \\ School of Politics, Xiangtan University \\ Xiangtan 411105, Hunan, China \\ Tel: 86-731-5829-3172 E-mail: hj1975xtu@xtu.edu.cn
}

This article is the research result of major projects of the base of law study in Hunan Province (N0.07FX06029)

\begin{abstract}
Both China and South Africa are developing countries that have explored a road of constitutional protection of human rights which is accordant with its National Conditions and national characteristics. There are similarities and differences on constitutional protection of human rights between the two countries. Constitutional protection of human rights in South Africa is deeply influenced by western constitution. China's constitution puts special emphasis on regulations on obligation as well as emphasizes the fundamental rights of citizens. It is decided by the National Conditions and the practice for development in the two countries.
\end{abstract}

Keywords: China's Constitution, Constitution of South Africa, Protection of human rights, The national conditions

Protection of human rights is the main content and basic principle of the modern constitution and constitutionalism. John Locke said, human rights are not only the basis of one country's legislation, but also the supreme principle that must be obeyed. Thus, whether the constitution's regulations contain the aspects of human rights and whether its operation is according to protection of human rights, are the primary value objectives of allowing people to advocate constitution, endorse constitution and hoping others' recognition of the constitution. The constitution is a piece of paper with people's rights on it. This means that the constitution is a book of the fundamental protection of human rights, especially for the fundamental rights. The fundamental rights of citizens are also called constitutional rights of citizens, and they are the primary, fundamental and decisive rights recognized by the constitution. All the countries in the world at present that are advocating democracy and freedom, their constitutions will contain the regulations on the fundamental rights of citizens almost invariably. There are similarities and differences on constitutional protection of human rights between China and South Africa. 1. The comparison of constitutional design of structure and constitutional model concerning the
fundamental rights between the two countries

1.1 The comparison of constitutional design of structure concerning the fundamental rights between the two countries

In terms of constitutional design of structure concerning the fundamental rights, the new constitution in South Africa has drawn lessons mainly from the constitutions of Germany, France and the United States. In the eyes of constitutional design of structure, the constitutions of Germany, France and the United States put the fundamental rights on the beginning of constitutions. Similarly, the new constitution in South Africa puts regulations concerning the fundamental rights of citizens in Chapter 2 (The bill of rights) in the form of special chapter. The kind of constitutional design of structure concerning the fundamental rights indicates that all countries attach importance to issues on rights and protection of rights .In addition, the new constitution in South Africa makes a programmatic declaration on the fundamental human rights before listing the fundamental rights, and stresses the importance of protecting the fundamental rights of the people of all nationalities in the preface and Chapter 1, in order to express the country's basic attitude to human rights.

In terms of constitutional design of structure concerning the fundamental human rights, there are still some drawbacks in the constitutional protection of human rights in our country. In general either expressing human rights by declaration, or regulating human rights in constitution, there will be special chapter or some special 
provisions designed in the constitutional documents that regulate the fundamental human rights of citizens, that is to say, making a programmatic declaration on the fundamental human rights before listing the details of human rights and fundamental rights, in order to express the country's basic attitude to human rights. The United Nations Charter, The Universal Declaration of Human Rights and some other important international human rights treaties, are always stressing to reassert protection the fundamental rights, and the principle of the fundamental human rights has been one universal constitutional principle. There are many countries' constitutions making a programmatic declaration on the human rights, or principled or concrete provisions intimating protection of the fundamental human rights clearly in the preface or related chapters .The current constitution of China put "Respect and protection of human rights" stressed publicly in the fifteenth and sixteenth National Party Congress's reports into the new amendment. In more specific terms, it is in Article 33 of Chapter 2 (the fundamental rights of citizens). This is not entirely proper. The writer thinks that it may be put it into the general programme in the form of special provision, or into the beginning of Chapter 2 as a programmatic declaration, in order to develop and consolidate the constitutional concept of the fundamental human rights.

\subsection{The comparison of constitutional model concerning the fundamental rights between the two countries}

According to whether classifying the regulations of the fundamental rights of citizens, there are two main models concerning the constitution of the fundamental rights of citizens in all the countries in the world: no classification of constitutional model and classification of constitutional model. No classification of constitutional model is also called itemized constitutional model, which means regulating the fundamental rights of citizens point by point. For example, there are four western countries including France, the United States, Germany and Britain, whose constitutions belong to no classification of constitutional model according to models concerning the constitutionalism of the fundamental rights .Classification of constitutional model regulates the fundamental rights of citizens by the way of dividing them into several categories. Since the emergence of The Universal Declaration of Human Rights and International Convention for human rights, all countries' constitutions have classified the regulations of the fundamental rights of citizens respectively according to classification of constitutional model referring to these three international documents about human rights. Under the influence of colonial rule, constitutional model concerning the fundamental rights in South Africa uses no classification of constitutional model of four western countries for reference. The current constitution of South Africa regulates the fundamental rights of citizens point by point from Article 7 to Article 39. It is noteworthy that the constitution of South Africa stresses the principle of human rights in the preface and Chapter 1 (fundamental provisions).

China's constitutional model concerning the fundamental rights is similar to South Africa, belonging to no classification of constitutional model. China's constitution regulates the fundamental rights and obligations of citizens point by point in the way of list. Unlike South Africa, China's constitution of socialism has a notable feature of the expression of the principle of the fundamental human rights: China's first 3 constitutions of socialism and the first 3 amendments of the 4th constitution of socialism did not write "human rights", but only regulated citizens' political rights, economic rights, cultural rights and such rights in every aspect of social life in a systematic way. Taking a comprehensive view of China's constitutions, they did not use the words of "human rights", "the fundamental human rights", "protection of human rights" whether in the preface or the main body before the fourth amendment of the 1982 constitution came out. To some extent, this had an impact on the construction of China's security system of the fundamental human rights and the smooth development of the cause of human rights. It also provided a pretext for the western countries to attack the issue of China's human rights. On March 14, 2004, the fourth amendment of the 1982 constitution was adopted and it put forward "our country respect and protect human rights". This has made history of declaring the principle of the fundamental human rights in China's constitution of socialism. And to a certain extent, this has adapted to the demand of modern constitutionalism and the protection of human rights.

\section{The comparison of the regulations of the main content concerning the fundamental rights between the two countries' constitutions}

\subsection{The main content concerning the fundamental rights in the constitution in South Africa}

The constitution in South Africa regulates the fundamental rights of citizens in detail in the form of special chapter in Chapter 2 (The bill of rights). The main content can be summarized as follows: (1) the right of equality:" equality includes the complete and equal enjoyment of all rights and freedom", "the state can not discriminate against anybody in an unfair way directly or indirectly for one or more reasons". (2) personal and individual rights and liberty, including: personal right to dignity and live, the right to liberty and security. the 
right of privacy, the right to religious toleration and freedom of speech, the right to freedom of expression, the right to freedom of movement and residence. (3) political rights, including: the right to vote and the right to be elected, the right of assembly, demonstration, petition ,association and political choice.(4) The economic and social rights ,including: the right of business, employment and occupational freedom, the rights of labor relations. the right to environmental protection, the right to the property, the right to housing, the rights to health care, food, water and social security.(5) the right to cultural and educational aspects, including: the right to education, language and culture ,the right of access to information.(6) Children ' s rights.(7) judicial rights, including: the right to submitting a case to the court., the rights of people who are arrested or accused. (8) the right of fair management.

\subsection{The main content concerning the fundamental rights in China's constitution}

New China has issued four constitutions and related amendments to confirm the fundamental rights of citizens since it was established. New China's first constitution_- the constitution of 1954 has 14 articles regulating the fundamental rights of citizens. The second constitution in the period of 10-year catastrophe — the constitution of 1975 has only 4 articles regulating the fundamental rights of citizens. Restricted by historical conditions, the third constitution_ _ the constitution of 1978 has also only 12 articles regulating the fundamental rights of citizens. After the reform and opening-up, our country's legislature began to give more attention to rights. Many legislations show the thoughts of control of power and protection of rights. The constitution of 1982 meets the demand of the socialist democracy and the rule of law, and the requirements of satisfying people's aspirations for protection of human rights. It has a comprehensive regulation of the fundamental rights of citizens. Subsequently, there were four amendments in 1988, 1993, 1999 and 2004, modifying 31 articles in total .There are 14 modified articles in total in the fourth amendment, and articles that matter to the fundamental human rights include: respect and protect human rights, improve the system of protection of private property, improve the system of commandeering land, establish and improve the social security system, etc.

China's current constitution's regulations of the fundamental rights of citizens include: the right of equality; the right to vote and the right to be elected; the freedom of speech, publication, assembly, association ,demonstration; the right to religious toleration; inviolability of citizens' personal liberty, dignity of personality and domicile, the freedom and privacy of correspondence are protected by law; the right to work, the right to rest, the right to obtaining help and the right to protection of retired personnel's life; the right to education; the liberty of conducting scientific research, literary and artistic creation and other cultural activities; women enjoy equal rights with men; the right of marriage, family, he aged, children protected by law; protect the rights and interests of overseas Chinese, returned overseas Chinese and the family members of Chinese nationals residing abroad.

\section{The comparison of the restrictions and the special regulations of the fundamental rights between the two countries' constitutions}

\subsection{The restrictions and the special regulations of the fundamental rights in the constitution in South Africa}

The fundamental rights are not unrestricted, and the constitution in South Africa also has regulations concerning the restrictions of the fundamental rights. The constitution of 1966 in South Africa regulated in its Article 36 like this: The rights in this Bill of Civil Rights are restricted based on dignity of personality, equality, liberty, and under the reasonable and lawful condition in an open and democratic society, according to the generally applicable laws. All related factors taken into consideration include: the nature of the right; the importance of the purpose of restriction; the nature and extent of restriction; the relationship between restriction and the purpose of restriction; the fewer regulated means to achieve purpose. Excepting the above regulations or other provisions, there is no law that can restrict the established rights in this Bill of Civil Rights. In addition, the constitution of 1966 in South Africa had regulations concerning declaring a state of emergency and restoring peace and order.

The constitution in South Africa also has regulations concerning the special regulations of the fundamental rights. The constitution in South Africa regulates in the preface like this," establishing a society based on democratic value, social justice and the fundamental human rights "in South Africa; "In this society, the government is based on the will of people and every citizen enjoys equal protection by law". The constitution put "the acquisition of personal dignity and equality and the progress of human rights and liberty", "non-racialism and non-sexist" and "the right to adult general election" as "value basement" of the establishment of South Africa in Article 1, Chapter 1 (the fundamental provision). The new constitution in South Africa summarizes the fundamental rights of citizens in Article 7, Chapter 2 (The Bill of Rights) like this :The Bill of Rights is considered as the cornerstone of democracy in South Africa, it remembers the rights of all people of South Africa and confirms the personal dignity and the value of equality and liberty, the state must respect, protect, improve and realize the rights in The Bill of Rights.And Article 8 regulates that "The Bill of Rights is applicable to all laws and it is 
binding to the legislation, administration, judicature and all state organs". From the regulations presented above, the fundamental rights of citizens in the constitution in South Africa are not the general provisions, and they are treated as "value basement" and "the cornerstone of democracy". They are the highest principle in all aspects of social life in South Africa.

\subsection{The restrictions and the special regulations of the fundamental rights in China's constitution}

While China's constitution regulates all kinds of fundamental rights and obligations of citizens, it also has specific provision like this: "Citizens of The People's Republic of China must not harm national, social, collective interests, and other citizen's legal liberty and rights." Paragraph 3 of Article 33 in China's current constitution provides that: "Every citizen enjoys the rights and at the same time must perform the duties prescribed by the Constitution and the law." This provision indicates that our citizens are the subjects of both rights and duties. From the view of the nature of state, our country is the socialistic country that people is master in his own house, therefore every citizen enjoys the rights prescribed by the Constitution and the law, and this indicates the status of them as masters of the country. But the prosperity of our country is the prerequisite and guarantee for the enjoyment of rights and liberty. Thus, faithfully performing the duties prescribed by the Constitution and the law is not only the demand of citizens' immediate interests, but also the demand of promoting the development of socialism and transforming our country into a modern and powerful socialist state, therefore it is the obligation of citizens certainly.

China's constitution provides that , citizens enjoy every right and liberty at the same time must perform the duties as follows: to safeguard national unity and territorial integrity; to abide by the Constitution and the law, to protect country's secrets, to take proper care of public property, to observe labour discipline, to observe public order, to observe social morality; to safeguard the security, honor and interests of the motherland; to defend the motherland, to perform military service or to join militia according to law; to pay tax according to law; the duty to work; the duty to receive education; both husband and wife have the duty to practice family planning; parents have the duty to rear and educate their minor children, and children who have come of age have the duty to support and assist their parents.

In conclusion, both China and South Africa are developing countries, and have probed out a road to constitutional protection of human rights which is accordant with its national conditions and national characteristics. There are similarities and differences on constitutional protection of human rights between the two countries. It is decided by the national conditions and the practice for development in the two countries. The two countries should strengthen the communication and cooperation in the constitutional protection of human rights, and make unremitting efforts to promote the international protection of human rights.

\section{References}

Bai, Gang, Lin, Guanghua. (2005). An introduction to constitutionalism. Social Science Academic Press, p.187.

Guan, Jinhua. (2003). The protection and legal practice of fundamental human rights. Xiamen University Press, p.303.

Han, Dayuan. (2005). Foreign Constitutions. Renmin University of China Press, p.421-423.

Lenin. (1987). The Collected Works of Lenin (Section 12). The People Press, p.50.

Xiao, Beigeng. (2002). The thought of constitutional legal order. Chinese People's Public Security University Press, p.64.

Yang, Haikun. (2004). New theory of constitutional fundamental rights. Beijing University Press, p.3. 